\title{
Thermal Analysis of GCLs at a Municipal Solid Waste Landfill
}

\author{
J. L. Hanson ${ }^{1}$, N. Yesiller ${ }^{2}$, and G. E. Swarbrick ${ }^{3}$ \\ ${ }^{1}$ Department of Civil Engineering, Lawrence Technological University, 21000 W. \\ Ten Mile Rd., Southfield, MI 48075, PH (248) 204-2538, FAX (248) 204-2568, \\ email: hanson@ltu.edu \\ 2 Department of Civil and Environmental Engineering, Wayne State University, 5050 \\ Anthony Wayne Dr., Detroit, MI 48202, PH (313) 577-3766, FAX (313) 577-3881, \\ email: yesiller@eng.wayne.edu \\ ${ }^{3}$ School of Civil and Environmental Engineering, University of New South Wales, \\ UNSW Sydney, NSW 2052, Australia, PH +61-2-9385-5016, FAX +61-2-9385- \\ 6139, email: g.swarbrick@unsw.edu.au
}

\begin{abstract}
This study was conducted to determine long-term thermal regime of landfill liner systems using a field temperature monitoring program and numerical analysis of heat transfer. Temperatures in liner systems that contain geosynthetic clay liners (GCLs) were monitored prior and subsequent to waste placement. Data were collected in three cells at a landfill in Midwestern USA for more than five years. The liner system in one of the cells was left exposed (not covered with waste) for a period exceeding one year subsequent to cell construction. The lowest and highest GCL temperatures were $-1^{\circ} \mathrm{C}$ and $35^{\circ} \mathrm{C}$, respectively and the localized temperature gradients ranged from approximately $-186^{\circ} \mathrm{C} / \mathrm{m}$ to $+134^{\circ} \mathrm{C} / \mathrm{m}$ across the liner system during the exposed period. Seasonal temperature fluctuations were dampened and increasing temperature trends were observed after placement of the first lift of waste over the liner systems. Temperatures in liners reached $30^{\circ} \mathrm{C}$ under 5 -year-old waste with an annual rate of temperature increase of approximately $4^{\circ} \mathrm{C} / \mathrm{a}$. In general, average temperature gradients decreased, however, high variations in gradients remained subsequent to waste placement. Numerical analysis was used for exposed liner systems to model observed behavior and to predict liner response under varied conditions. Good agreement was observed between measured and predicted temperatures. Temperature distributions in liners were determined for variable thicknesses of sand protective layers in 3 climatic regions. Sand thicknesses of more than $1 \mathrm{~m}$ were required to maintain temperatures between 0 and $40^{\circ} \mathrm{C}$ and thicknesses on the order of $3 \mathrm{~m}$ were required to limit seasonal temperature variations to within $10^{\circ} \mathrm{C}$ in GCLs.
\end{abstract}




\section{Introduction}

GCLs are used commonly in containment systems for bottom liner systems as well as for cover liner systems. GCLs are subjected to coupled effects of environmental and operational stresses in the field including mechanical, hydraulic, chemical, and thermal stresses. Temperature affects properties and behavior of GCLs (Rowe 1998). In general, detailed spatial or temporal distributions or comprehensive long-term trends for GCL field temperatures are not available. Also, heat transfer in liner systems has not been analyzed extensively in the past. This study was conducted to determine long-term temperature trends in GCL liners in the field. Onset and duration of temperature variations with respect to local air and ground temperatures have been studied. Thermal gradients in a liner system were determined. Heat transfer through GCL liner systems was investigated using numerical analysis.

\section{Background}

Physical, mechanical, and hydraulic properties of GCLs are determined in the laboratory for manufacturing quality control and for conformance and acceptance testing. Baseline mechanical properties, hydraulic properties, and fluid transport characteristics of GCLs have been determined at temperatures near $20^{\circ} \mathrm{C}$. The response of GCLs was investigated for variable placement conditions, stress conditions, permeant liquids, and environmental exposure conditions (Rowe 1998). These tests have generally been conducted in the laboratory at standard laboratory conditions even though the test materials may have experienced variable temperatures during certain stages of tests (e.g., cyclic freeze/thaw and wet/dry tests).

Properties and response of GCLs are affected by temperature. Freeze/thaw and desiccation of GCLs are controlled by field temperatures. Fluid transport through GCLs is affected by temperature directly due to viscosity and dielectric constant effects and indirectly due to moisture content effects. Also, thermally driven fluid transport (thermoosmosis) occurs in soils. Diffusion is a critical mechanism for fluid transport in low hydraulic conductivity materials (including both clay and geomembrane components of GCLs). The free solution diffusion coefficient, $\mathrm{D}_{\mathrm{o}}$, for species common in MSW leachate (Rowe et al. 1995) and the soil diffusion coefficient, D, for a clay soil beneath a landfill (Crooks and Quigley 1984) both increased with temperature. Ion and potential distributions adjacent to charged clay particles, which can affect the microstructure of the soil, are sensitive to temperature (Mitchell 1993). In addition, temperature influences mechanical response of clay soils and it is expected that the same effects will be present in GCLs. Furthermore, durability of geosynthetic components of GCLs is affected by temperature.

Several studies of temperatures at the base of landfills (near liner systems) under waste-covered conditions have been reported in geotechnical literature. Yoshida and Rowe (2003) reported temperatures between approximately 20 and $50^{\circ} \mathrm{C}$ at the base of three landfills in Japan. The temperatures were monitored for 12 to 30 years using sensors that were installed between 7 and 10 years after initial waste placement. Generally, temperatures were high at the onset of the monitoring periods and decreased with time. An average temperature of $14^{\circ} \mathrm{C}$ was observed for no leachate 
mounding and increasing temperatures in the range of 20 to $37^{\circ} \mathrm{C}$ were measured for high leachate mounding at the base of a landfill in Canada over a 7-year period (10 to 17 years after waste placement) [Rowe 1998]. Gartung et al. (1999) reported temperatures between 20 and $40^{\circ} \mathrm{C}$ underneath wastes that were more than 10 years old and more than $50^{\circ} \mathrm{C}$ underneath 6 to 8-year old wastes at a German landfill. Dach and Jager (1995) indicated that temperatures in excess of $50^{\circ} \mathrm{C}$ were measured at the base of landfills in Germany. Koerner (2001) reported temperatures between 20 and $35^{\circ} \mathrm{C}$ for a liner with GCL in Pennsylvania monitored over 9.5 years. The cell was covered by the end of the third year of monitoring. The temperatures were near $20^{\circ} \mathrm{C}$ for the first 5.5 years and then increased. Liner temperatures of 10 to $30^{\circ} \mathrm{C}$ and 20 to $30^{\circ} \mathrm{C}$ were reported for landfills in California and Florida, respectively (Rowe 1998).

Temperatures of bottom liner systems were recorded in winter months to determine extent of freezing of the liners that were exposed for several years at 2 landfills in Germany (Dullmann and Hilpusch 1997). Temperatures below $0^{\circ} \mathrm{C}$ were measured within the clay liners in both landfills, with higher frost penetration depths observed for clay overlain by a geomembrane than clay overlain by gravel. Remedial measures included excavation of clay and use of polystyrene insulation. Rodatz and Voigt (1997) recommended site-specific heat transfer analysis and use of insulation to prevent freezing of soil liners in Central Europe based on laboratory and field test plot investigations of compacted clay liners. They also indicated that a 1-m-thick waste layer would provide insulation to the underlying liners.

Numerical analysis was used to investigate heat transfer in waste-covered soil liners. Doll (1997) and Heibrock (1997) used one-dimensional nonlinear differential equations of heat transfer to assess thermally driven moisture flow and desiccation cracking of compacted clay liners. The models had provisions for heat transfer as well as water and water vapor transfer for unsaturated conditions in the soil liner. Yoshida and Rowe (2003) used one-dimensional nonlinear differential equations of heat transfer to predict temperatures in a landfill and the underlying soil. The model had provisions for heat flow due to conduction and water transport and for heat generation due to decomposition of the waste. Detailed modeling of heat transfer in exposed liners (before waste placement) has not been commonly reported.

Limited data is available on long-term field temperatures of GCLs including onset and duration of temperature variations and thermal gradients. Also, heat transfer analysis has not been reported for GCLs. The study described in this paper was conducted to investigate the thermal regime of liner systems using field monitoring and numerical analysis. The field monitoring portion of the study is an ongoing investigation. Even though preliminary data were reported elsewhere by Yesiller and Hanson (2003), all of the liner temperature data obtained at the site is reported herein. Temperatures are reported for exposed and waste-covered conditions in the liners. A numerical model was developed to predict temperatures within an exposed bottom liner system. The model was used to provide recommendations for thickness of protective cover layers (insulating layers) to be placed over liner systems to limit excessive seasonal temperature and thermal gradient fluctuations in the liner systems. 


\section{Field Investigation}

This study is conducted at a municipal solid waste landfill located in Michigan, U.S.A. The site is in an area that has a humid continental temperate climate. The climatological conditions at the site are reported for the period 1999 to 2003 . The annual normal average high and low temperatures were $15.1^{\circ} \mathrm{C}$ and $5.5^{\circ} \mathrm{C}$, respectively. The annual normal precipitation and the average snowfall at the site were $868 \mathrm{~mm}$ and $1068 \mathrm{~mm}$, respectively. The average barometric pressure was 103 $\mathrm{kPa}$ and the average relative humidity was $70.6 \%$. The seasonal ground surface temperatures at the site typically varied between $-1^{\circ} \mathrm{C}$ and $30^{\circ} \mathrm{C}$. The mean annual earth temperature measured at depth at the site was $11.7^{\circ} \mathrm{C}$. The landfill is located in an area with silty clay soils to typical depths of $21 \mathrm{~m}$ underlain by hardpan (stiff layer consisting of cemented sand and fine gravel) and bedrock at a depth of approximately $23 \mathrm{~m}$. The water content of the clay ranges from approximately 10 to $12 \%$ and the unit weight of the clay is $22 \mathrm{kN} / \mathrm{m}^{3}$. A confined aquifer is located at the hardpan/bedrock elevations. Excavations for the construction of individual cells extend to depths of approximately 10 to $13 \mathrm{~m}$ below original ground surface.

The landfill consists of 11 cells: 8 existing cells and 3 future cells. The liner systems of 3 existing cells (Cells J, I, and D) were instrumented for this study. The cells have similar single composite liner systems, which consist of (from top to bottom): 450mm-thick protective sand layer, nonwoven needle-punched PP geotextile / HDPE geonet (GT/GN), 1.5-mm-thick HDPE geomembrane (GM), and needle-punched laminated GCL (mass/unit area of $3660 \mathrm{~g} / \mathrm{m}^{2}$ ). Cell $\mathrm{J}$ (area $3.2 \mathrm{ha}$ ) was constructed in 1998 and filled with waste from 1999 to 2001. Cell I (area 3.5 ha) was constructed in 1999 and filled from 2000 to 2002. Cell D (area 5.2 ha) was constructed in 2001 and has been filled since December 2002. Waste is generally placed in constant height lifts that cover the entire base area of a cell. Such a lift generally has an accumulated thickness of $4 \mathrm{~m}$ and is placed over a period of approximately 40 days. The average waste column heights in Cells J, I, and D are 44 m, 31 m, and 17 m, respectively.

Temperatures are measured using thermocouple sensor arrays. An array consists of a series of wires beginning at a monitoring box and terminating at various points along a linear path. Type K thermocouple wires consisting of Nickel alloys (Ni-Cr/Ni-Mn$\mathrm{Al})$ were selected for their resistance to chemical environments. The configurations of the sensor arrays are presented in Figure 1. Arrays were placed within the sand layer in all three cells (Type A). In Cell D, two additional arrays were used: Type B array was placed on the proof-rolled subgrade immediately below the GCL, parallel to the array within the sand layer, and Type $C$ array was placed vertically below the GCL in the underlying subgrade approximately $95 \mathrm{~m}$ away from the edge of the cell. The long arrays start near the mid-section of a perimeter edge of a cell and extend towards the center of a cell. Type A arrays were installed in Cells J and I in March and November 1999, respectively followed by waste placement within 2 to 3 months. The liner system in Cell D was constructed between September and December 2001. Types B and C arrays were installed below the GCL in September 2001 and a Type A array was installed in the sand in December 2001. The liner system was left exposed for more than a year until waste placement started in December 2002. 

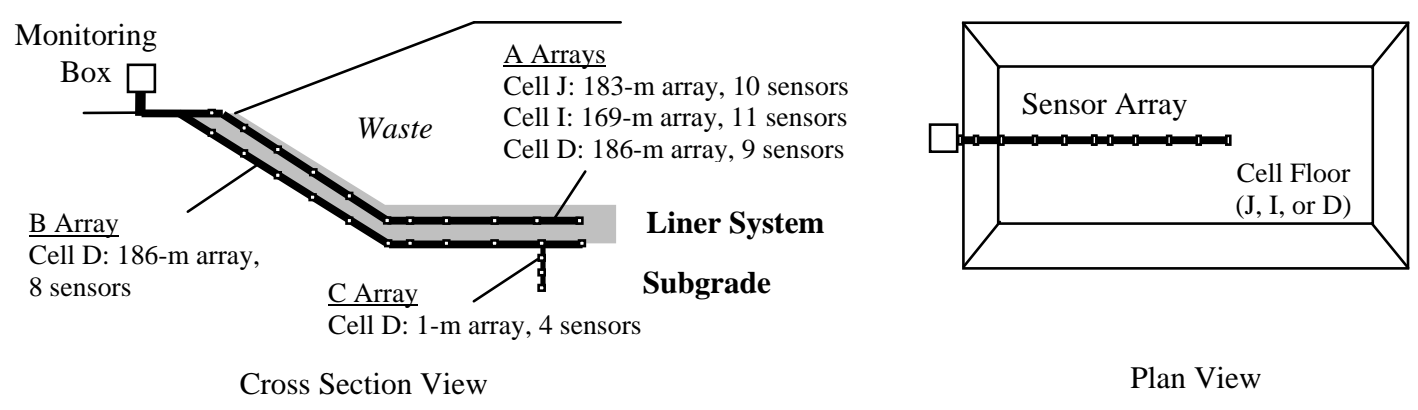

Plan View

Figure 1. Configuration of sensor arrays (not to scale).

\section{Numerical Model}

Numerical modeling was used to complement the experimental study. In particular, modeling was used for exposed liner systems to predict liner response under varied conditions. A well established numerical model, the comprehensive transport simulator, STOMP (Subsurface Transport Over Multiple Phases), was used in the study (White et al. 1995). STOMP can be used to predict movement of heat, gas, and liquid as well as cross-phase components (e.g., water vapor, dissolved air within water) in three dimensions through variably saturated porous media. The partial differential equations used to predict heat, liquid, and gas transport are solved using a Newton-Raphson linearization technique (White et al. 1995). The model allows for determination of temperature variations across a liner system with time due to applied climatic loads including temperature, precipitation, relative humidity, and barometric pressure. Heat flow is modeled using conductive and convective heat transfer.

The numerical analysis was conducted using 1-D simulations, as the modeled area was located near the center of the landfill where heat transfer was essentially 1-D. In addition, limited data on material properties would limit the reliability of 2-D or 3-D analysis. The analysis was conducted using the liner system profile underlain by the native subgrade at the field site (Table 1). The upper boundary was subjected to changes in ground surface temperature, barometric pressure, relative humidity, and water pressure (to simulate rainfall). No energy or gas flux was allowed at the lower boundary where the water pressure was fixed at a constant value representing saturation and the temperature was fixed at the mean annual earth temperature, $11.7^{\circ} \mathrm{C}$. The thickness of the clay represented the subgrade thickness after cell construction. A total of 18 nodes were used to model the transport of heat, liquid, and gas through the vertical profile in response to climatic conditions. Variable time steps were used in the simulation, with a range from 0.001 days to 0.1 days.

The applied ground surface temperatures were derived from air temperatures that were modified to account for radiation absorption and emission effects by using ground surface freezing and thawing n-factors (Andersland and Ladanyi 2003). For the exposed sand surface, a thawing n-factor of 1.5 and a freezing n-factor of 0.9 were used. These factors are normally applied on a seasonal basis. However, in this study, n-factors were applied on a daily basis to better capture temperature extremes. The maximum and minimum daily temperatures were adjusted so that the total freezing or thawing energy applied to the surface by a bi-modal linear model was 
equal to that applied from a daily sinusoidal temperature variation and the energy applied to the surface by the linear model was adjusted by the freezing or thawing factors. Freezing or thawing energy is the area bound by the temperature-time curve and the $0^{\circ} \mathrm{C}$ baseline (area below $0^{\circ} \mathrm{C}$ for freezing, area above $0^{\circ} \mathrm{C}$ for thawing).

Table 1. Parameters used in numerical analysis.

\begin{tabular}{l|r|r|r|r|r}
\hline Larameter & \multicolumn{1}{c|}{ Land } & GT/GN & \multicolumn{1}{c|}{ GM } & \multicolumn{1}{c}{ GCL } & \multicolumn{1}{c}{ Clay } \\
\cline { 1 - 6 } Thickness $[\mathrm{mm}]$ & $450^{\mathrm{a}}$ & $8^{\mathrm{d}}$ & $1.5^{\mathrm{d}}$ & $8.5^{\mathrm{f}}$ & $10,000^{\mathrm{a}}$ \\
\hline Density $\left[\mathrm{t} / \mathrm{m}^{3}\right]$ & $1.7^{\mathrm{a}}$ & $0.15^{\mathrm{d}}$ & $0.93^{\mathrm{d}}$ & $0.81^{\mathrm{b}}$ & $1.98^{\mathrm{a}}$ \\
\hline Porosity & $0.34^{\mathrm{b}}$ & $0.83^{\mathrm{d}}$ & $0.0001^{\mathrm{b}}$ & $0.7^{\mathrm{b}}$ & $0.26^{\mathrm{a}}$ \\
\hline Long-term water content $\left[\mathrm{M}_{\mathrm{w}} / \mathrm{M}_{\mathrm{s}}\right]$ & $0.02-0.2^{\mathrm{b}}$ & $0.05-5.0^{\mathrm{b}}$ & $0^{\mathrm{b}}$ & $0.70^{\mathrm{g}}$ & $0.11^{\mathrm{a}}$ \\
\hline Air entry pressure $[\mathrm{m}]$ & $0.1^{\mathrm{b}}$ & $0.05^{\mathrm{b}}$ & $1^{\mathrm{b}}$ & $0.4^{\mathrm{b}}$ & $0.1^{\mathrm{h}}$ \\
\hline Brooks-Corey $\lambda^{\mathrm{b}}$ & $1^{\mathrm{b}}$ & $2^{\mathrm{b}}$ & $1^{\mathrm{b}}$ & $0.01^{\mathrm{b}}$ & $0.05^{\mathrm{h}}$ \\
\hline Hydraulic conductivity $[\mathrm{m} / \mathrm{s}]$ & $1 \times 10^{-5 \mathrm{~b}}$ & $1.25 \times 10^{-2} \mathrm{e}$ & $1 \times 10^{-14 \mathrm{~b}}$ & $5 \times 10^{-12 \mathrm{~d}}$ & $1 \times 10^{-9 \mathrm{~h}}$ \\
\hline Thermal conductivity $\left[\mathrm{W} / \mathrm{m} /{ }^{\circ} \mathrm{C}\right]^{\mathrm{c}}$ & $0.25-2$ & $0.04-0.5$ & 0.27 & 0.16 & $0.15-2$ \\
\hline Mass heat capacity $\left[\mathrm{J} / \mathrm{kg} /{ }^{\circ} \mathrm{C}\right]^{\mathrm{c}}$ & 1600 & 2245 & 3000 & 300 & 1800 \\
\hline
\end{tabular}

$\mathbf{a}$ from site records, $^{\mathbf{b}}$ estimated, $^{\mathbf{c}}$ from Andersland and Ladanyi (2003), thermal properties were modeled as linearly dependent on saturation (completely dry to fully saturated), ${ }^{\mathbf{d}}$ based on manufacturer's data, ${ }^{\mathbf{e}}$ estimated from transmissivity using manufacturer's data, ${ }^{\mathbf{f}}$ based on data presented in Erickson and Thiel (2002), ${ }^{\mathbf{g}}$ result of long-term equilibrium with underlying clay from numerical simulation, ${ }^{\mathbf{h}}$ The hydraulic properties for the clay were estimated using data from Miller et al. (2002) for similar material.

The procedure used to adjust observed daily maximum, $T_{\max }$, and minimum, $T_{\min }$ air temperatures was as follows:

For thaw or freeze only mode: $T_{\max } \times T_{\min }>0$

$$
\begin{aligned}
& T_{\max }^{\prime}=n_{t / f}\left[\frac{T_{\max }(\pi+4)+T_{\min }(\pi-4)}{2 \pi}\right] \\
& T_{\min }^{\prime}=n_{t / f}\left[\frac{T_{\max }(\pi-4)+T_{\min }(\pi+4)}{2 \pi}\right]
\end{aligned}
$$

where $T^{\prime}{ }_{\text {max }}$ min are the adjusted maximum/minimum ground temperatures and $n_{t / f}$ is the thaw/freeze factor as appropriate.

For thaw and freeze mode: $T_{\max } \times T_{\min }<0$

$$
\begin{aligned}
& T_{\max }^{\prime}=2\left(n_{t} A_{1}+\sqrt{-n_{t} A_{1} n_{f} A_{2}}\right) \\
& T_{\min }^{\prime}=2\left(n_{f} \mathrm{~A}_{2}+\sqrt{-n_{t} A_{1} n_{f} A_{2}}\right)
\end{aligned}
$$

where $A_{1}$ and $A_{2}$ are the areas under the temperature curve above and below freezing:

$$
A_{1}=\frac{\left[T_{\max }-T_{\min }\right]}{2 \pi} \sqrt{1-\left[\frac{T_{\max }+T_{\min }}{T_{\max }-T_{\min }}\right]^{2}}+\frac{\left[T_{\max }+T_{\min }\right]}{4 \pi}\left[\pi-2 \sin ^{-1}\left(\frac{T_{\max }+T_{\min }}{T_{\min }-T_{\max }}\right)\right]
$$




$$
A_{2}=\frac{\left[T_{\max }+T_{\min }\right]}{2}-A_{1}
$$

Climate data were obtained from NCDC (2004) for a 10-year period for the field site. For two additional sites (Tucson, AZ and Juneau, AK), 10-year climate records were simulated using the CliGen climate generation model (USDA 2004). These sites were selected for their climate extremes. Factored ground temperatures were determined using the approach described above for the 3 sites (Table 2). Additional ground temperature data is presented for the field site for the monitoring period during exposed conditions (September 1, 2001 to December 31, 2002; 456 days).

Table 2. Summary of ground temperature data used in modeling.

\begin{tabular}{l|r|r|r|r}
\hline \hline \multicolumn{1}{c|}{ Parameter } & Field Site $^{\mathbf{a}}$ & Field Site & Tucson, AZ & Juneau, AK \\
\hline Maximum ground temp $\left[{ }^{\circ} \mathrm{C}\right]$ & 36.1 & 37.8 & 47.2 & 31.3 \\
\hline Minimum ground temp $\left[{ }^{\circ} \mathrm{C}\right]$ & -16.1 & -23.3 & -7.6 & -27.5 \\
\hline Average ground temp $\left[{ }^{\circ} \mathrm{C}\right]^{\mathrm{b}}$ & 11.7 & 11.7 & 30.2 & 7.9 \\
\hline a Observed maximum/minimum during the monitored period \\
Average ground temperature for the field site was determined from field measurements. For \\
Tucson and Juneau these were determined from factored ground temperatures.
\end{tabular}

\section{Results and Discussion}

Initially, field results are provided, followed by verification of the model, results of model sensitivity, and model prediction analyses. Temperature data at the field site have been collected on a weekly basis since March 6, 1999. Variations of temperature with time for the various sensor arrays are provided in Figures 2 and 3. Air temperatures are also presented. In addition, distances of sensors with respect to a monitoring box and dates for waste placement are indicated on the figures.

Liner temperatures vary with seasonal temperature fluctuations prior to waste placement (Figure 2). Data from locations near the edge of Cell $\mathrm{D}(15 \mathrm{~m})$ and near the center of the cell $(186 \mathrm{~m})$ are presented in Figure 2a. The liner system was in place for approximately 15 months prior to the start of waste filling. The magnitudes of sand and GCL liner temperatures were generally similar to seasonal air temperatures, while the variations were somewhat less than that for air temperatures (Figure 2a). A majority of GCL temperatures was close to the upper boundary of the measured air temperature envelope. Temperatures below the liner also vary with seasonal temperature fluctuations prior to waste placement (Figure 2b). Subgrade temperatures near the surface vary more than temperatures at deeper locations due to seasonal temperature fluctuations in accordance with conventional seasonal ground temperature theory. The data indicate an average phase lag of 35 days and an amplitude decrement of approximately 4 to $7^{\circ} \mathrm{C}$ across the sensor array (from sand sensor to 825-mm Type $\mathrm{C}$ sensor) prior to waste placement (Figure 2b).

The fluctuations of temperatures decreased significantly due to placement of the first lift of waste (approximately $4 \mathrm{~m}$ ). Subsequently, temperatures started increasing steadily with time (Figure 2a). The variation of temperatures at the $15 \mathrm{~m}$ sensor continued as the waste coverage date was later and the depth of waste coverage was 
significantly less than that for the $186 \mathrm{~m}$ sensor. The $15 \mathrm{~m}$ sensor has been covered with only $1.2 \mathrm{~m}$ of waste/temporary soil cover material due to its location at the crest of the side slope in Cell D. Therefore, complete damping of seasonal temperature fluctuation was not observed at the $15 \mathrm{~m}$ sensor. Temperatures of the sand, GCL, and underlying subgrade stabilized due to placement of the first lift of waste and subsequently started increasing steadily with time (Figure 2b). High variation in temperatures was observed $75 \mathrm{~mm}$ below the liner for approximately 3 to 6 months after placement of waste potentially due to a temporary malfunction of the sensor.

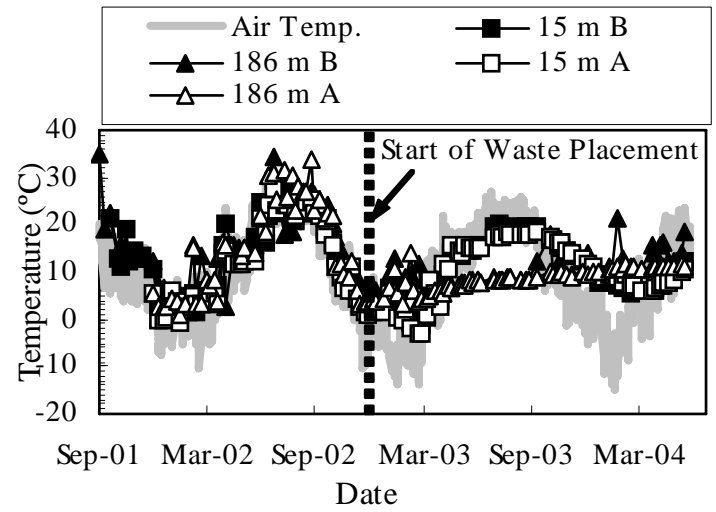

a) Center vs. edge comparison

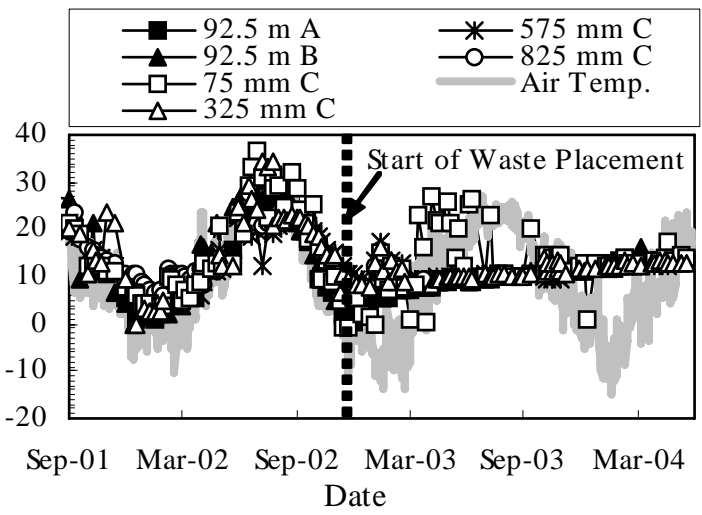

b) Profile beneath liner system

\section{Figure 2. Liner temperatures in Cell D.}

The temperatures for Type A sensor arrays (above GCL) for all three cells (J, I, and D) are presented in Figure 3. It was observed that liner temperatures near the edge of the cells were undergoing seasonal fluctuations, whereas the temperatures near the center are relatively steady demonstrating increasing trends subsequent to waste placement. Seasonal temperature fluctuations in the liner systems are dampened significantly due to the placement of the first constant waste height of $4 \mathrm{~m}$ over the liner system, except at the edge of a cell. Temperatures have reached $30^{\circ} \mathrm{C}$ at liner locations near the center of Cell $\mathrm{J}$ under approximately 5-year-old waste, corresponding to a maximum waste height of $43 \mathrm{~m}$ over the sensors. Temperatures have reached $21^{\circ} \mathrm{C}$ at liner locations near the center of Cell I under approximately 4year-old waste, corresponding to a maximum waste height of $43 \mathrm{~m}$. Temperatures have reached $17^{\circ} \mathrm{C}$ at liner locations near the center of Cell $\mathrm{D}$ under approximately 1.5-year-old waste, corresponding to a maximum waste height of $26 \mathrm{~m}$. The rates of temperature increase in the liners were determined using linear regression curve fits of temperature vs. time data for a period of 400 days beginning 5 months after waste placement. The resulting rates of temperature increase in the liners are approximately 2.9, 3.6, and $5.2^{\circ} \mathrm{C} /$ a for Cells J, I, and D, respectively. Lower rates observed in Cell $\mathrm{J}$ are attributed to relative seasonal cooling. Waste placement in Cell $\mathrm{J}$ started in summer with cooler weather following whereas waste placement started in winter for both Cells I and D, which was followed by warmer weather. 

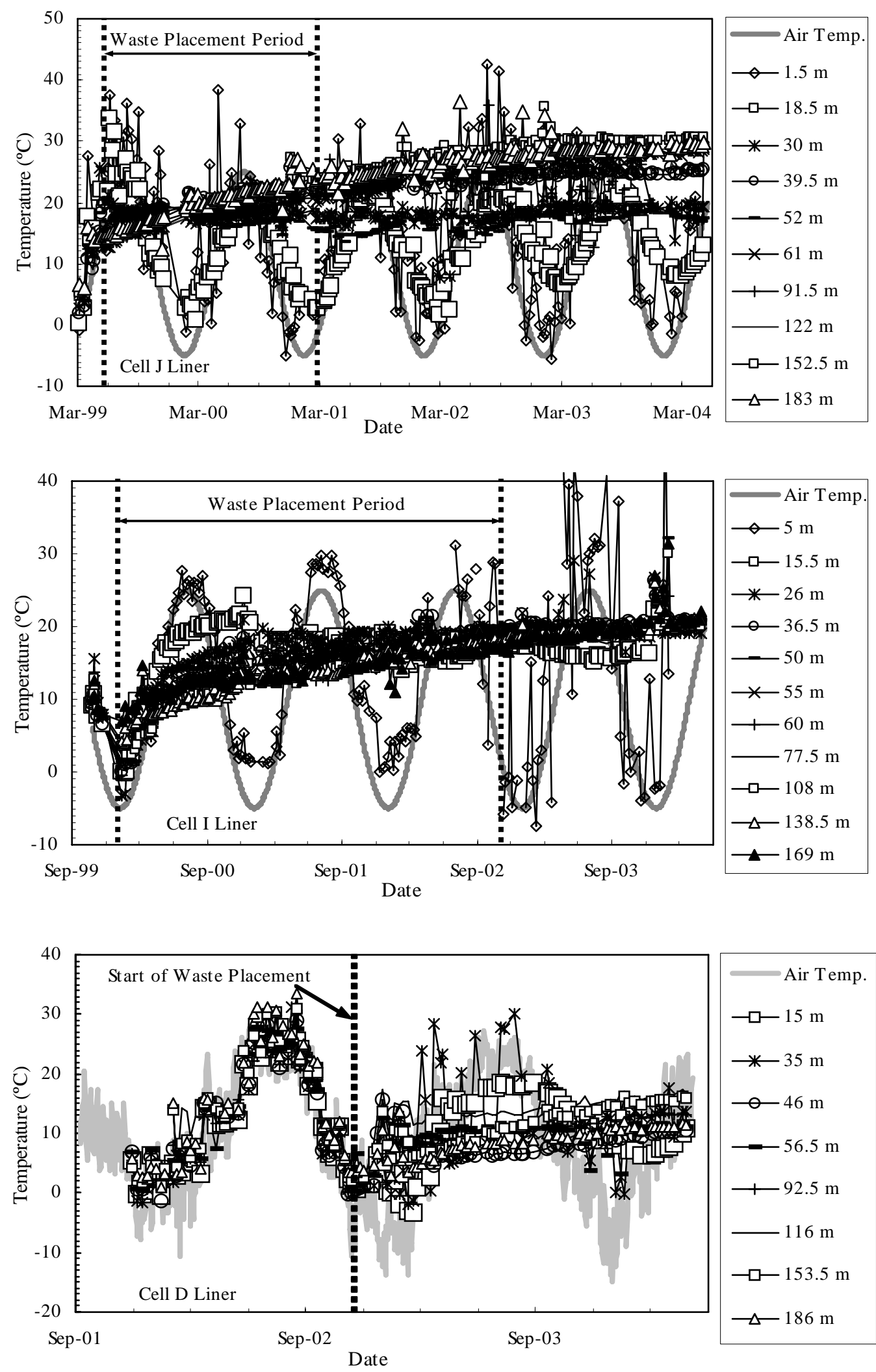

Figure 3. Field temperatures for 3 liner systems. 
Localized temperature gradients were determined as the quotient of the temperature difference between two sensors to the distance between the sensors at locations in the vicinity of the liner system in Cell D. For gradients across the liner system, the difference between sand (Type A) and GCL (Type B) temperatures at a given location was used. The vertical distance between these sensors was estimated to be $100 \mathrm{~mm}$. For gradients immediately below the liner system, temperature difference between the 92.5-m-GCL (Type B) sensor and the 75-mm Type C sensor were used. For gradients further below the liner system, temperature difference between adjacent pairs of Type $\mathrm{C}$ sensors were used.

Thermal gradients for the liner are presented in Table 3 for exposed and waste covered conditions. The ranges of measured instantaneous gradients are significant, even though the average gradients vary between -8 and $+4^{\circ} \mathrm{C} / \mathrm{m}$ (except immediately below liner gradient after waste placement). The majority of gradients was negative (corresponding to upward heat flow) for exposed conditions. Across liner and below liner gradients became predominantly positive after waste placement (corresponding to downward heat flow). The highest average absolute value gradients are measured immediately below the liner system. Positive gradients decreased significantly and negative gradients increased upon waste placement except for locations immediately below the liner. The high scatter in the data from the sensor located $75 \mathrm{~mm}$ below the liner (Figure 2b) was suspected to be the cause for this unique trend. Additional calculations were made by ignoring the period between December 2002 and July 2003 at the beginning of the waste placement period (Table 3). The removal of the portion of data exhibiting high scatter caused a reduction in gradient magnitudes, but did not change the predominant direction of heat flow. The localized negative gradients immediately below the liner are therefore considered valid and are attributed to seasonal fluctuations or presence of relatively cool leachate just above the liner system. Each of these conditions might result in a relatively warm localized zone directly beneath the liner system. The high degree of variation in the measured gradients indicates the complexity of the thermal dynamics of landfill liners. Longterm monitoring of site-specific conditions is warranted to quantify these trends.

Table 3. Summary of temperature gradients.

\begin{tabular}{|c|c|c|c|c|}
\hline & Parameter & Across Liner & $\begin{array}{l}\text { Immediately } \\
\text { Below Liner }\end{array}$ & Below Liner \\
\hline \multirow{4}{*}{ 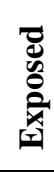 } & Ave. Gradient $\left({ }^{\circ} \mathrm{C} / \mathrm{m}\right)$ & -7.8 & -4.4 & -0.2 \\
\hline & Measured Range $\left({ }^{\circ} \mathrm{C} / \mathrm{m}\right)$ & -186 to +134 & -149 to +289 & -50 to +87 \\
\hline & Avg. Absolute Gradient $\left({ }^{\circ} \mathrm{C} / \mathrm{m}\right)$ & 25.7 & 37.5 & 11.2 \\
\hline & \% Negative Gradients & 66 & 58 & 57 \\
\hline \multirow{4}{*}{ 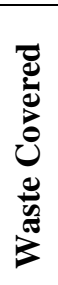 } & Average Gradient $\left({ }^{\circ} \mathrm{C} / \mathrm{m}\right)$ & +2.4 & $\begin{array}{l}-39.9 \\
-5.0 *\end{array}$ & $\begin{array}{l}+3.7 \\
+0.60 *\end{array}$ \\
\hline & Measured Range $\left({ }^{\circ} \mathrm{C} / \mathrm{m}\right)$ & -137 to +260 & $\begin{array}{l}-259 \text { to }+137 \\
-57.3 \text { to }+40 *\end{array}$ & $\begin{array}{l}-42 \text { to }+76 \\
-42 \text { to }+37 *\end{array}$ \\
\hline & Avg. Absolute Gradients $\left({ }^{\circ} \mathrm{C} / \mathrm{m}\right)$ & 16.3 & $\begin{array}{l}52.3 \\
8.4^{*}\end{array}$ & $\begin{array}{l}5.7 \\
2.2 *\end{array}$ \\
\hline & \% Negative Gradients & 48 & $\begin{array}{l}79 \\
71^{*}\end{array}$ & $\begin{array}{l}38 \\
35 *\end{array}$ \\
\hline
\end{tabular}


Results of the numerical analysis are presented for: model verification, sensitivity analysis, broader application, and design predictions. The performance of the numerical model was verified by comparing the model results to the field data for exposed conditions (Figure 4). Model results for GCL and sand temperatures are presented in Figure 4 for all measurement locations. Generally, good agreement was observed between measured and predicted temperatures. A period of limited agreement was observed for a particularly wet period in the spring of 2002. It is believed that saturated conditions prevailed in the sand for an extended period due to more than $380 \mathrm{~mm}$ of rain that fell in 21 days. This dampened temperature fluctuations significantly which was not fully captured by the numerical model that indicated increasing temperatures over the period. Nevertheless, the high temperatures that were measured following this period were effectively captured using the model.
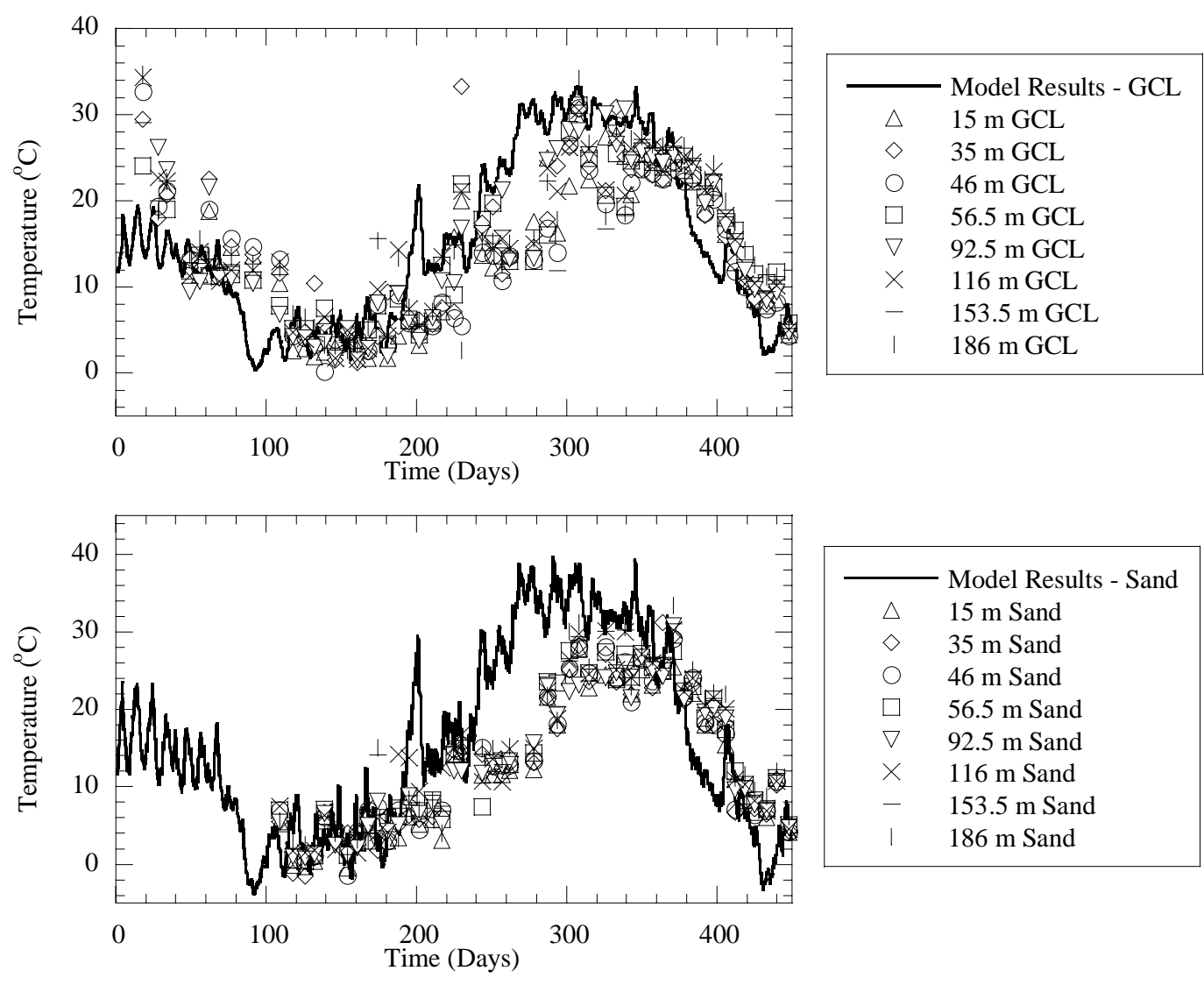

Figure 4. Model results compared to field measurements.

Model performance was further evaluated by comparing distributions of measured average gradients for all sensor pairs across the liner with model results (Figure 5). The percentages of measured gradients that exceed various threshold gradients are presented for positive, negative, and absolute value gradients for exposed and covered conditions for field results whereas positive and negative gradients for exposed conditions are presented for model results. This analysis allows evaluation of model performance as well as the effect of waste placement on field-measured 
gradients. Model results follow the general trends of field measurements with similar gradient distributions and predominantly negative gradients. The effects of waste placement were observed in the field data (Figure 5). Localized gradients across the liner system decreased upon placement of waste (corresponding to a shift in curves) even though the range of gradients measured after waste placement was greater than the range before waste placement.

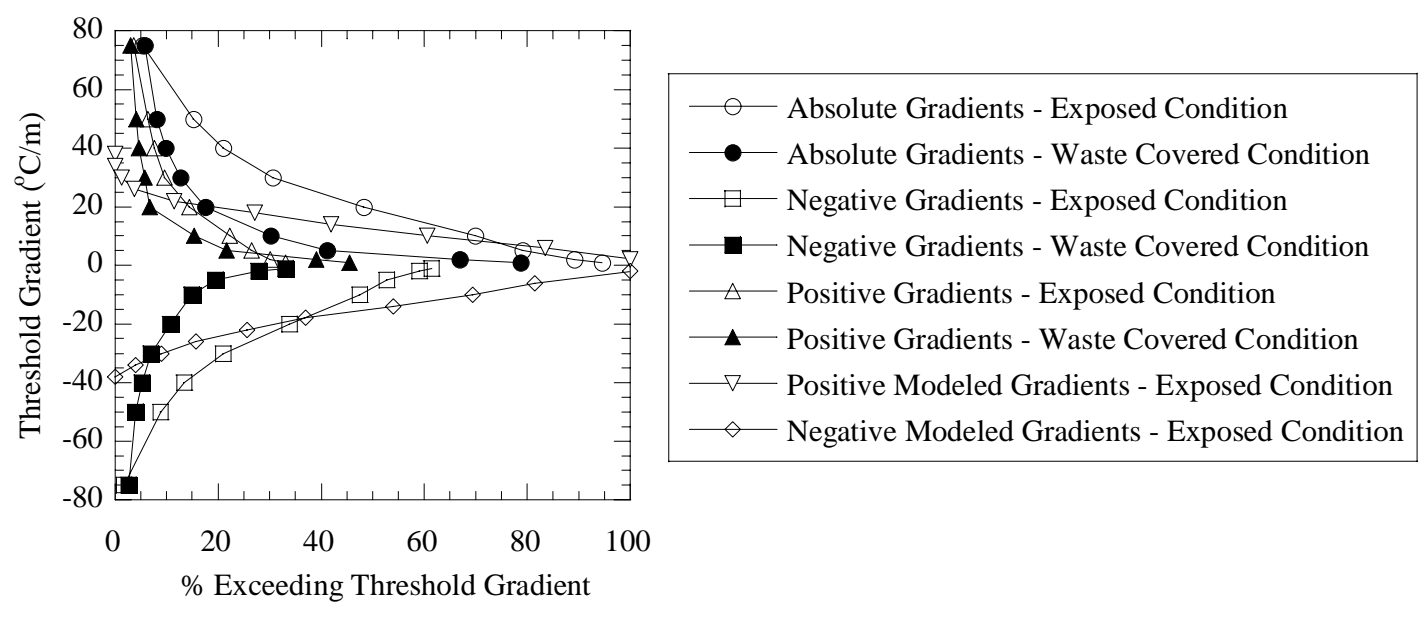

Figure 5. Distribution of thermal gradients.

Sensitivity of the model was evaluated using heat, liquid, and gas transport in various combinations; varying degrees of saturation for the sand and GT/GN composite; and varying thermal properties for the liner system. Effects of the varying conditions on predicted temperatures and gradients were determined. Preliminary analysis was conducted to analyze the effects of fluid flux on heat transfer. Heat flux in combination with liquid and gas flux, heat flux in combination with gas flux only, and heat flux with no liquid or gas flux were modeled. It was observed that convective heat transfer (liquid or gas) had limited influence on GCL response. Then, the effect of degree of saturation on GCL response was investigated using: heat flux, liquid and gas flux under normal conditions ('normal' case), heat flux alone with a saturated sand and GT/GN layer ('wet'), and heat flux alone with a dry sand layer ('dry'). The GCL responses for normal and wet cases were similar as the sand and GT/GN were generally close to fully saturated. Seasonal ground temperature fluctuations were dampened considerably for the dry case causing smaller temperature ranges, larger gradients, and smaller depths of freezing than the wet case. The differences between wet and dry cases resulted from the significant differences in thermal properties of the materials for the two conditions (saturated and dry). Finally, the effects of thermal properties were investigated by first increasing the thermal conductivity, $k_{h}$, and decreasing the mass heat capacity, $C_{p}$, for all layers by $10 \%$ and second, by decreasing $k_{h}$ and increasing $C_{p}$ for all layers by $10 \%$. Small changes in the thermal properties have limited influence on GCL response.

Broader application of the model was evaluated by conducting a 10-year simulation for the test site (Figure 6). Results of the extended prediction demonstrate that the 
liner system undergoes high temperature variations in exposed conditions (maximum GCL temperature $35.4^{\circ} \mathrm{C}$; minimum GCL temperature $-5.1^{\circ} \mathrm{C}$; all ten summer seasons GCL temperature greater than $30^{\circ} \mathrm{C}$; eight of ten winter seasons freezing GCL conditions). The results also indicate high variation in thermal gradients in the vicinity of GCL. This analysis indicates that extreme temperatures and gradients are expected to occur in liner systems in Michigan during any exposed period, and that these conditions are not limited to the period of observation between 2001 and 2002.

Table 4. Sensitivity analysis.

\begin{tabular}{l|r|r|r|r|r}
\hline \hline \multicolumn{1}{c|}{ Parameter } & \multicolumn{1}{c|}{ Normal } & \multicolumn{1}{c|}{ Wet } & Dry & $\begin{array}{c}k_{h}+10 \% \\
C_{p}-10 \%\end{array}$ & $\begin{array}{c}k_{h}-10 \% \\
C_{p}+10 \%\end{array}$ \\
\hline Temperature range $\left[{ }^{\circ} \mathrm{C}\right]$ & 0.1 to 33.7 & 0.1 to 34.7 & 7.7 to 20.4 & -0.2 to 34.1 & 0.4 to 33.2 \\
\hline Average temp $\left[{ }^{\circ} \mathrm{C}\right]$ & 14.8 & 15.1 & 13.3 & 14.8 & 15.6 \\
\hline Gradient range $\left[{ }^{\circ} \mathrm{C} / \mathrm{m}\right]^{\mathrm{a}}$ & -31.4 to +38.9 & -33.9 to +42.2 & -51.3 to +75.6 & -32.3 to +41.6 & -30.4 to +37.8 \\
\hline Gradient average $\left[{ }^{\circ} \mathrm{C} / \mathrm{m}\right]^{\mathrm{a}}$ & 13.5 & 13.0 & 28.6 & 13.6 & 13.4 \\
\hline Depth of freezing $[\mathrm{mm}]$ & 463 & 462 & 176 & 466 & 456 \\
\hline
\end{tabular}

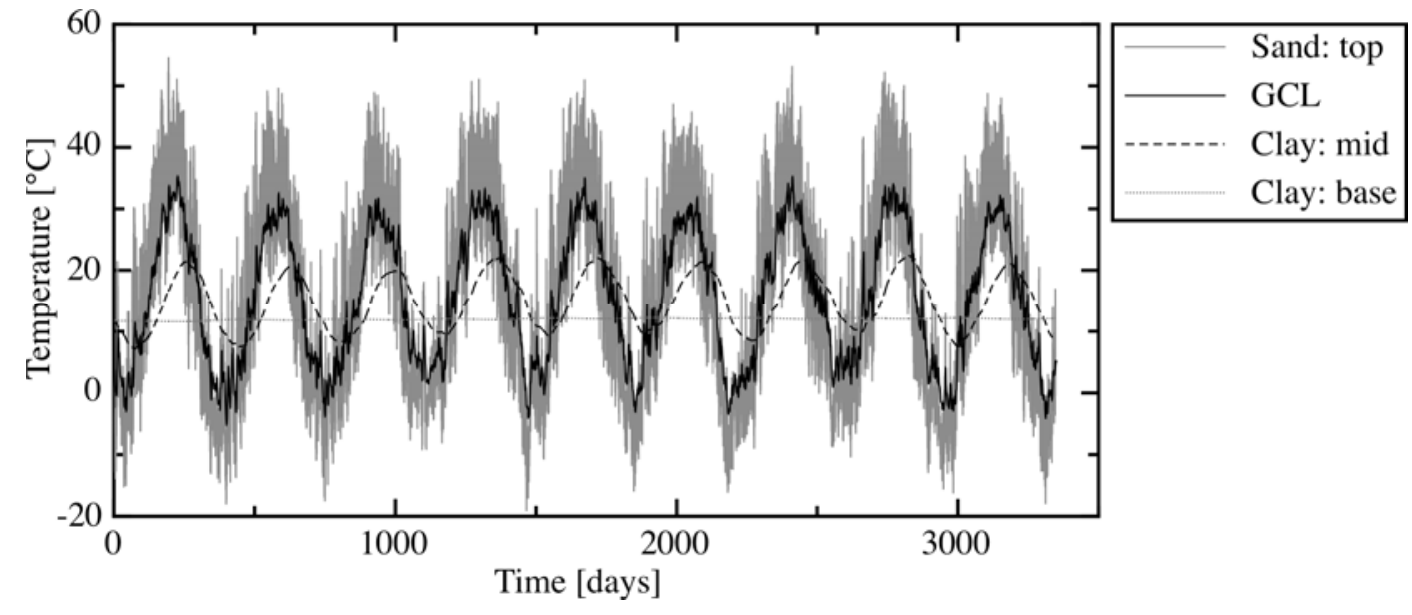

Figure 6. Results from 10-year simulation.

Finally, design predictions were made to evaluate required depth of sand cover to maintain temperatures within prescribed ranges in the GCL. The effects of thickness of the sand layer were investigated for liner configurations similar to those at the field site using 10-year climatic data for the field site as well as Arizona and Alaska. The sand depth was incrementally increased from $450 \mathrm{~mm}$ to $3000 \mathrm{~mm}$ and the resulting GCL temperatures are presented in Figure 7. The results indicate that GCL liners are subjected to temperature extremes even when they are protected by significant depths of sand. Such analysis should be conducted for liner systems that will remain exposed for extended periods. In cases with requirements for high sand depths, alternative insulating materials with different thermal properties may be considered. The model used in this study can be readily adapted to evaluate varying climatic conditions, liner configurations, and protective layer design. 


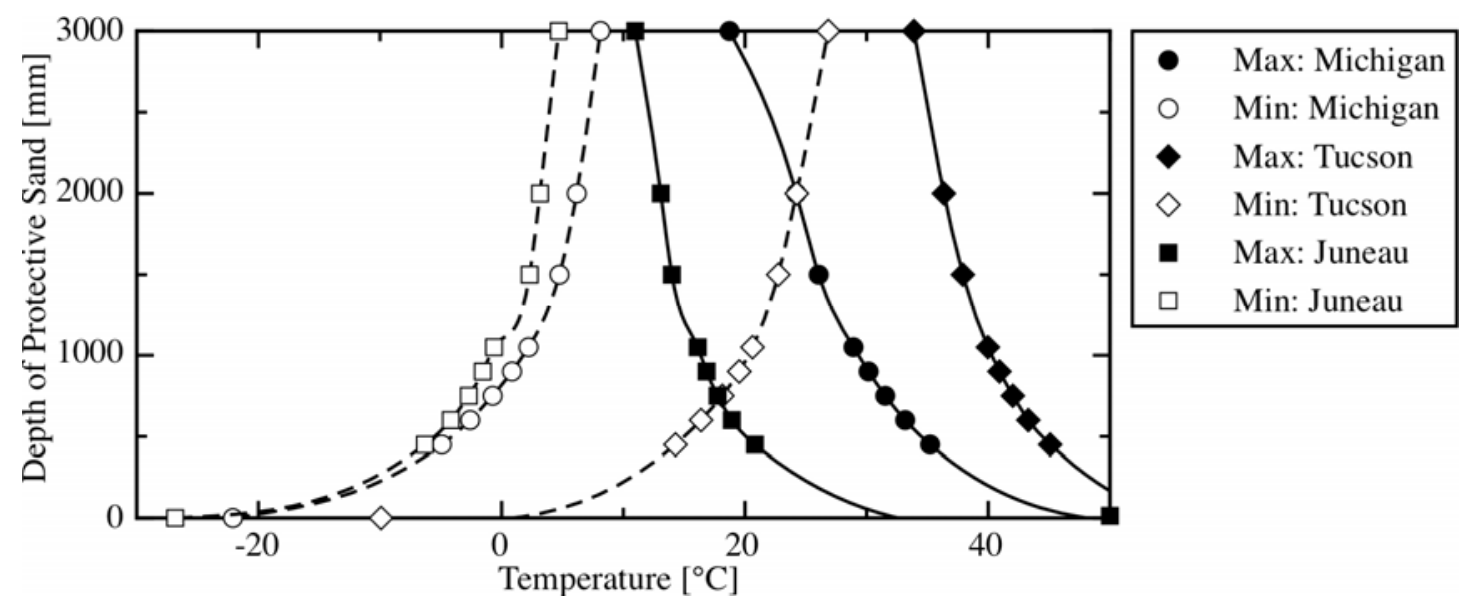

Figure 7. Predicted GCL temperatures under variable sand depths.

\section{Summary and Conclusions}

This study was conducted to determine long-term thermal response of GCL liners on a field scale. Temperatures in the vicinity of GCL liners were measured in three cells at a landfill located in Midwestern USA. Onset and duration of temperature variations with respect to local air and ground temperatures have been studied. Thermal gradients in the vicinity of the liner system were determined in one cell. Heat transfer through GCL liner systems were investigated using numerical analysis.

Temperatures in the vicinity of the GCL followed seasonal temperature variations under exposed conditions. The lowest and highest GCL temperatures were $-1^{\circ} \mathrm{C}$ and $35^{\circ} \mathrm{C}$, respectively and the localized temperature gradients ranged from approximately $-186^{\circ} \mathrm{C} / \mathrm{m}$ to $+134^{\circ} \mathrm{C} / \mathrm{m}$ across the liner system during the exposed period. It was observed that temperatures stabilized rapidly after placement of the first lift of waste over liner systems. Seasonal temperature fluctuations were dampened and increasing temperature trends were observed. Temperatures in liner systems reached $30^{\circ} \mathrm{C}$ under 5 -year-old waste with an annual rate of temperature increase of approximately $3^{\circ} \mathrm{C} / \mathrm{a}$. In general, average temperature gradients decreased, however, high variations in gradients remained subsequent to waste placement across and near GCL liners.

Numerical analysis was conducted to develop a predictive tool for estimating temperature variations in exposed liner systems. Generally good agreement was observed between field observations and model results. Subsequent to verification, the model was used to predict temperature distributions in liners under variable thickness of sand protective layers in 3 climatic regions. Sand thicknesses of more than $1 \mathrm{~m}$ were required to maintain temperatures between 0 and $40^{\circ} \mathrm{C}$ and sand thicknesses on the order of $3 \mathrm{~m}$ were required to limit seasonal temperature variations to within $10^{\circ} \mathrm{C}$ in GCLs. Overall, the field measurements and numerical analysis used in this study indicate that GCLs are subjected to high temperature variations and thermal gradients that are outside the range of the conditions that are typically considered in testing and design of these materials. Long-term monitoring of site- 
specific conditions is needed to fully quantify the complex thermal regime of liner systems. Heat transfer modeling can assist in establishing the baseline thermal trends expected in the field.

\section{Acknowledgement}

This study is supported by the National Science Foundation (GOALI Grant: CMS9813248, SGER Grant: CMS-0301032, and a 2004 AAAS/NSF WISC Grant). Mr. Wei-Lien Liu assisted with field work and data analysis. Assistance of the partner landfill is greatly appreciated.

\section{References}

Andersland, O. B. and Ladanyi, B. (2003). Frozen Ground Engineering (2nd edition), Wiley, NY.

Crooks, V. E. and Quigley, R. M. (1984). "Saline leachate migration through clay: a comparative laboratory and field investigation,” Canadian Geotechnical Journal, Vol. 21, p. 349-362.

Dach, J. and Jager, J. (1995). "Prediction of gas and temperature with the disposal of pretreated residential waste,” Proceedings, Sardinia 1995, Fifth International Waste Management and Landfill Symposium, Christensen, T. H. et al., eds., CISA, Italy, Vol. 1, p. 665-677.

Doll, P. (1997). "Desiccation below mineral liners with heat production," Journal of Geotechnical and Geoenvironmental Engineering, ASCE, Vol. 123, No. 11, p. 1001-1009.

Dullmann, H. and Hilpusch, J. (1997). "Influence of frost on fine-grained landfill liners and technical preventive measures,” Proceedings, Sardinia 1997, Sixth International Waste Management and Landfill Symposium, Christensen, T. H. et al., eds., CISA, Italy, Vol. 3, p. 115-129.

Erickson, R. B. and Thiel, R. (2002). "Design and application of the geomembrane supported GCL in one-product and encapsulated composite liner systems," International symposium on clay geosynthetic barriers, Zanzinger, H., et al., eds. Nuremberg, Germany, Balkema.

Gartung, E. (1999). "Performance of compacted clay liners at the base of municipal landfills: the Bavarian experience,” Proceedings, Sardinia 1999, Seventh International Waste Management and Landfill Symposium, Christensen, T. H. et al., eds., CISA, Italy, Vol. 3, p. 31-38.

Heibrock, G. (1997). “Desiccation cracking of mineral sealing liners,” Proceedings, Sardinia 1997, Sixth International Waste Management and Landfill Symposium, Christensen, T. H. et al., eds., CISA, Italy, Vol. 3, p. 101-113.

Koerner, G. (2001). "In situ temperature monitoring of geosynthetics used in a landfill," Geotechnical Fabrics Report, Vol. 19, No. 4, p. 12-13.

Miller, C. J., Yesiller, N., Yaldo, K., and Merayyan, S., (2002). "Impact of soil type and compaction conditions on soil water characteristic," Journal of Geotechnical and Geoenvironmental Engineering, ASCE, Vol. 128, No. 9, p. 733-742.

Mitchell, J. K. (1993). Fundamentals of soil behavior, $2^{\text {nd }}$ edition, Wiley, New York.

NCDC (2004). “Climate database,” National Climatic Data Center, last accessed: 1 June 2004, last updated: 5 March 2004, http://www.ncdc.noaa.gov/.

Rodatz, W. and Voigt, T. (1997). "Investigations into the frost susceptibility of mineral landfill liners, problems affecting stability and precautions to be taken,” Advanced landfill liner systems, August, H., Holzlohner, U., and Meggyes, T., eds. Thomas Telford, London, p. 333-349.

Rowe, R. K. (1998). "Geosynthetics and the minimization of contaminant migration through barrier systems beneath solid waste," Proceedings, Sixth International Conference on Geosynthetics, Rowe, R. K., ed., 25-29 March 1998, Atlanta, Georgia, p. 27-102.

Rowe, R. K., Quigley, R. M., and Booker, J. R. (1995). Clayey barrier systems for waste disposal facilities, E \& FN Spon (Chapman and Hall), London, 390 pp.

USDA (2004). “CliGen weather generator,” US Department of Agriculture, last accessed: 29 June 2004, last updated: 27 June 2004, http://horizon.nserl.purdue.edu/cligen/.

White, M. D., Oostrom, M. and Lenhard, R. J. (1995). "Modeling fluid flow and transport in variably saturated porous media with the STOMP simulator. 1. Nonvolatile three-phase model description," Adv. Water Resources, 18(6): 353-364.

Yesiller, N. and Hanson, J. L. (2003). "Analysis of temperatures at a municipal solid waste landfill," Proceedings, Sardinia 2003, Ninth International Waste Management and Landfill Symposium, Christensen, T. H. et al., eds., CISA, Italy.

Yoshida, H. and Rowe, R. K. (2003). “Consideration of landfill liner temperature,” Proceedings, Sardinia 2003, Ninth International Waste Management and Landfill Symposium, Christensen, T. H. et al., eds., CISA, Italy. 